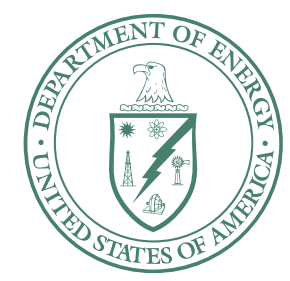

U.S. Department of Energy

Idaho Operations Office

\title{
Groundwater Monitoring Plan for the Reactor Technology Complex Operable Unit 2-13
}

March 2007 
DOE/ID-10626

Revision 6

Project No. 23361

\section{Groundwater Monitoring Plan for the Reactor Technology Complex Operable Unit 2-13}

March 2007

Prepared for the 


\begin{abstract}
This Groundwater Monitoring Plan describes the objectives, activities, and assessments that will be performed to support the ongoing groundwater monitoring requirements at the Reactor Technology Complex, formerly the Test Reactor Area. The requirements for groundwater monitoring were stipulated in the Final Record of Decision for Test Reactor Area, Operable Unit 2-13 signed in December 1997. The monitoring requirements were modified by the First Five-Year Review Report for the Test Reactor Area, Operable Unit 2-13, at the Idaho National Engineering and Environmental Laboratory to focus on those contaminants of concern that warrant continued surveillance, including chromium, tritium, strontium-90, and cobalt-60. Based upon recommendations provided in the Annual Groundwater Monitoring Status Report for 2006, the groundwater monitoring frequency was reduced to annually from twice a year.
\end{abstract}




\section{SUMMARY}

The Final Record of Decision for Test Reactor Area, Operable Unit 2-13 was signed in December 1997 and provided for groundwater monitoring to assess future contaminant concentrations at the Test Reactor Area (now Reactor Technology Complex) at the Idaho National Engineering and Environmental Laboratory (now Idaho National Laboratory Site). Based on recommendations provided in the First Five-Year Review Report for the Test Reactor Area, Operable Unit 2-13, at the Idaho National Engineering and Environmental Laboratory, groundwater monitoring requirements were modified to focus on those contaminants of concern that warrant continued surveillance including chromium, tritium, strontium-90, and cobalt-60. The diesel recurrence in Well PW-13 was also identified as an issue in the first 5-year review. This Groundwater Monitoring Plan describes the objectives, activities, and assessment procedures that will be performed to support the ongoing groundwater monitoring requirements as stipulated in the 5-year reviews.

Monitoring activities have been designed to verify the contaminant concentration trends in the Snake River Plain Aquifer, predicted by the Operable Unit 2-12 computer model, and to evaluate the effects that discontinued discharge to the warm waste pond have on the underlying water bodies. In addition, the deep-perched water system will be monitored for potential contaminant migration driven by continued discharges to the cold waste pond. To meet these objectives, groundwater monitoring will be performed on seven wells completed in the deep-perched water system (PW-11, PW-12, PW-14, PW-9, USGS-54, USGS-55, and USGS-56) and seven wells completed in the Snake River Plain Aquifer (Hwy-3, TRA-06A, TRA-07, TRA-08, USGS-58, USGS-65, and Middle-1823).

Water samples will be collected annually from the above wells for the four contaminants of concern that warrant continued groundwater monitoring, including chromium, tritium, strontium-90, and cobalt-60. In addition, PW-13, TRA-1933, and TRA-1934 will be sampled for diesel-range organics and gasoline-range organics to address the occurrence of diesel at these locations. 


\section{CONTENTS}

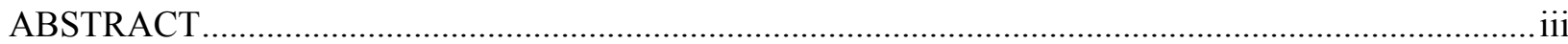

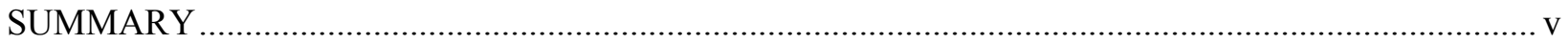

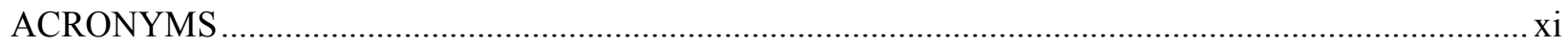

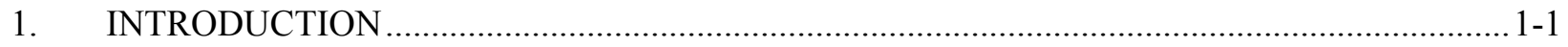

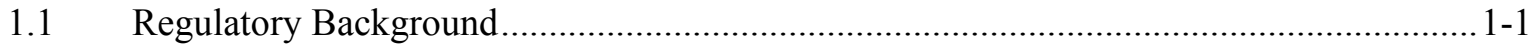

1.2 Groundwater Monitoring Plan.......................................................................... 1-2

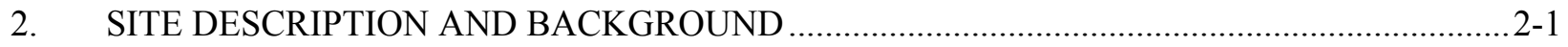

$2.1 \quad$ Source, Nature, and Extent of Contamination .............................................................

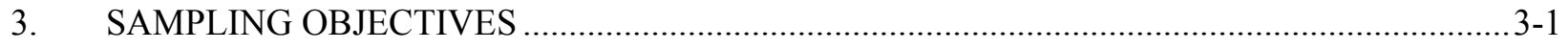

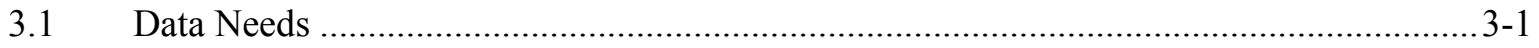

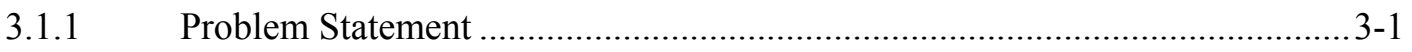

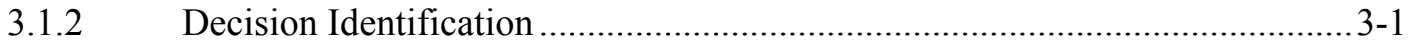

3.1.3 Identify Inputs to the Decision ...............................................................

3.1.4 Study Boundaries ..................................................................................

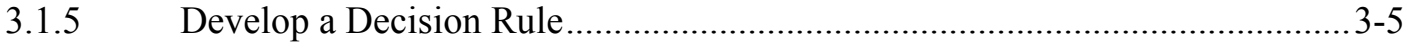

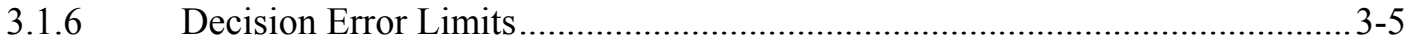

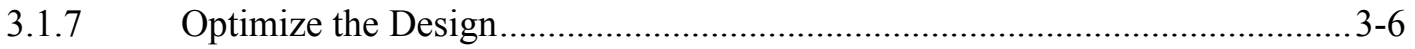

3.2 Quality Assurance Objectives for Measurement …....................................................... 3-7

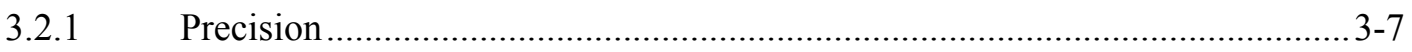

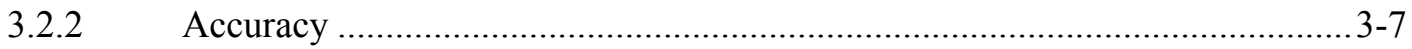

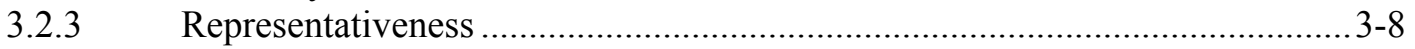

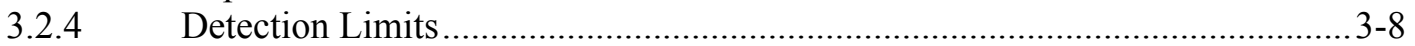

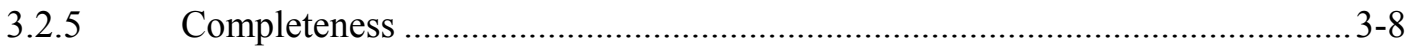

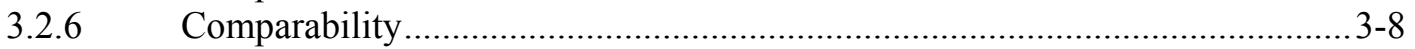

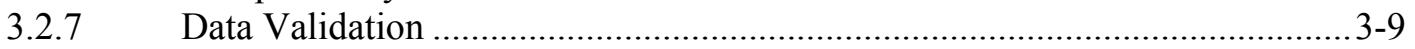

4. SAMPLING LOCATION AND FREQUENCY .................................................................

4.1 Quality Assurance/Quality Control Samples.............................................................. 4-1

4.2 Sampling Locations and Analytes ...................................................................... $4-1$

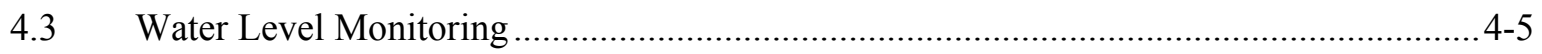

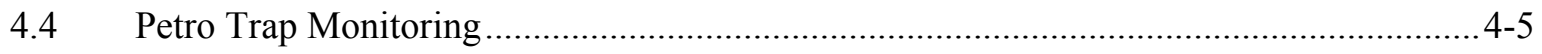




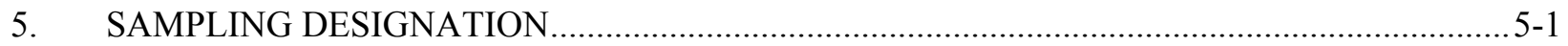

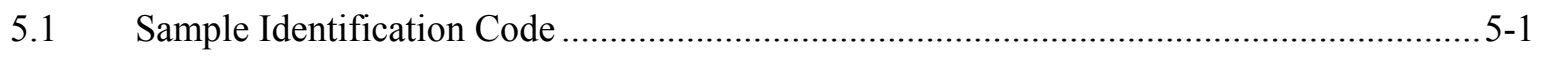

5.2 Sampling and Analysis Plan Table/Database ............................................................ 5-1

5.2.1 Sampling and Analysis Plan Table............................................................ $5-1$

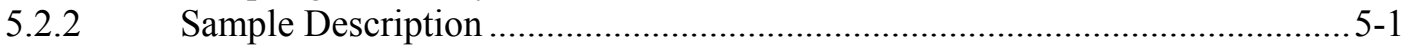

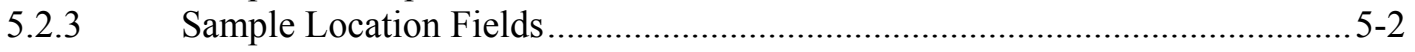

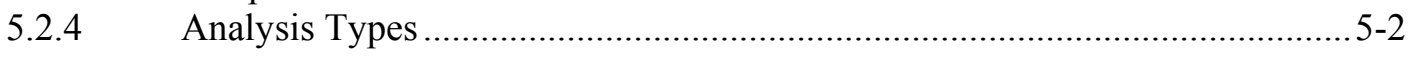

6. SAMPLING PROCEDURES AND EQUIPMENT …........................................................

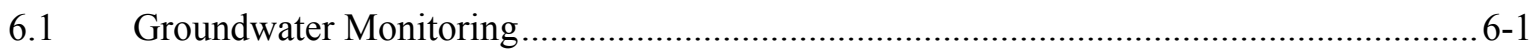

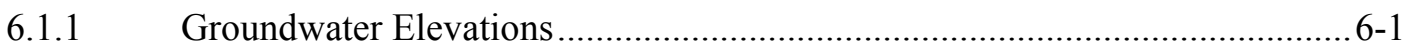

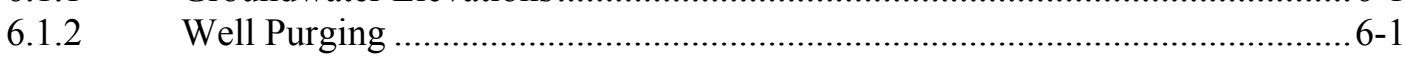

6.1.3 Groundwater Sampling ................................................................... $6-1$

6.2 Handling and Disposition of Remediation-Derived Waste ........................................... 6-2

7. DOCUMENTATION MANAGEMENT AND SAMPLE CONTROL .................................... $7-1$

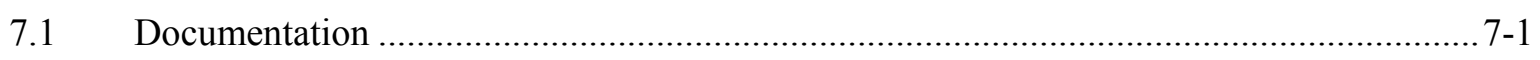

7.1.1 Sample Container Labels ....................................................................

7.1.2 Field Guidance Forms ................................................................

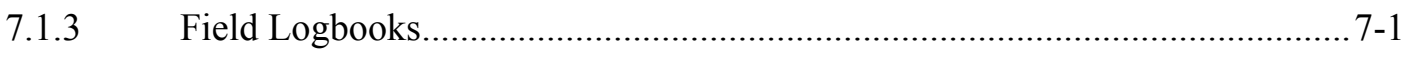

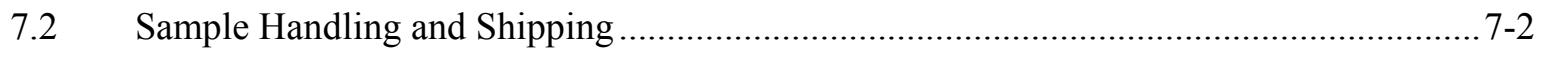

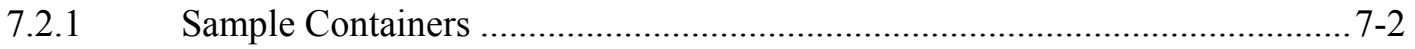

7.2.2 Sample Preservation......................................................................... $7-2$

7.2.3 Chain-of-Custody Procedures ............................................................... 7-2

7.2.4 Transportation of Samples .................................................................

7.3 Document Revision Requests............................................................................

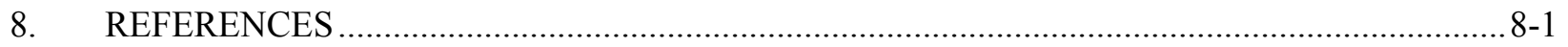




\section{FIGURES}

2-1. Map showing the location of the Idaho National Laboratory Site..............................................2-2

4-1. Map showing location of aquifer wells to be sampled at the Reactor Technology

Complex

4-2. Map showing location of perched wells to be sampled at the Reactor Technology

Complex

4-3. Water level measurement locations for perched and aquifer wells

4-6

\section{TABLES}

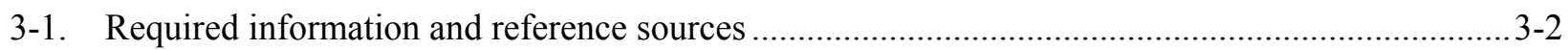

3-2. Information required for resolution of decision statements.................................................. 3-3

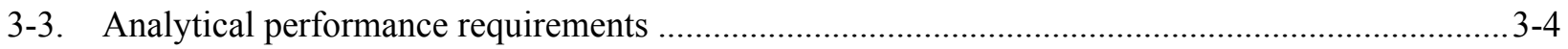

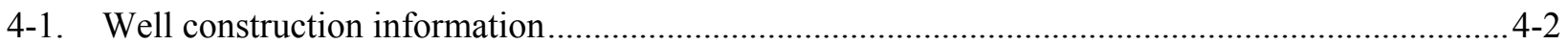




\section{ACRONYMS}

CERCLA Comprehensive Environmental Response, Compensation, and Liability Act

CFR Code of Federal Regulations

COC contaminant of concern

DOT U.S. Department of Transportation

DQO data quality objective

DR decision rule

DRO diesel-range organic

DS decision statement

EPA U.S. Environmental Protection Agency

FY fiscal year

GDE guide

GMP Groundwater Monitoring Plan

GRO gasoline-range organic

Hwy highway

ICP Idaho Cleanup Project

ID identification

IDAPA Idaho Administrative Procedures Act

INL Idaho National Laboratory

OU operable unit

PSQ principal study question

QA quality assurance

QAPjP Quality Assurance Project Plan

QA/QC quality assurance/quality control

QC quality control

RI/BRA remedial investigation/baseline risk assessment

RI/FS remedial investigation/feasibility study

ROD Record of Decision 
RTC Reactor Technology Complex

SAP Sampling and Analysis Plan

SRPA Snake River Plain Aquifer

TRA Test Reactor Area (now Reactor Technology Complex [RTC])

USGS United States Geological Survey

WAG waste area group 


\section{Groundwater Monitoring Plan for the Reactor Technology Complex Operable Unit 2-13}

\section{INTRODUCTION}

The Final Record of Decision for Test Reactor Area, Operable Unit 2-13 (DOE-ID 1997a) presents the selected remedial actions and provides for groundwater monitoring to assess future contaminant concentrations at the Reactor Technology Complex (RTC), formerly the Test Reactor Area (TRA), at the Idaho National Laboratory (INL) Site. This Groundwater Monitoring Plan (GMP) was originally developed to address the post-Record of Decision (ROD) monitoring requirements identified in the Operable Unit (OU) 2-13 ROD for the Snake River Plain Aquifer (SRPA) and the deep-perched water system at the RTC (DOE-ID 1997a). Based on the First Five-Year Review Report for the Test Reactor Area, Operable Unit 2-13, at the Idaho National Engineering and Environmental Laboratory (DOE-ID 2003), it was recommended that the monitoring effort should be focused on those contaminants of concern (COCs) that warranted continued surveillance.

The recurrence of diesel in PW-13 also was noted during the first 5-year review. An investigation into the recurrence of the diesel was completed (DOE-ID 2005), and the sampling effort confirmed that the product was old diesel.

This GMP describes the objectives, activities, and assessment procedures that will be performed to support the groundwater quality monitoring requirements as stipulated in the 5-year reviews. This plan has been prepared pursuant to 40 CFR 300, "National Oil and Hazardous Substances Pollution Contingency Plan," and is consistent with U.S. Environmental Protection Agency (EPA) guidance documents. This GMP is comprised of two parts: (1) the monitoring plan and (2) the Quality Assurance Project Plan (QAPjP). The monitoring plan describes the field-sampling activities that will be performed, while the QAPjP details the processes and programs that will be used to ensure that the data generated are suitable for their intended uses. The governing QAPjP for this sampling effort is the Quality Assurance Project Plan for Waste Area Groups 1, 2, 3, 4, 5, 6, 7, 10, and Removal Actions (DOE-ID 2006a). This document is incorporated herein by reference.

\subsection{Regulatory Background}

In December 1992, the ROD was issued for the OU 2-12 RTC perched water system (DOE-ID 1992). It was determined that no remedial action was necessary for the deep-perched water system to ensure protection of human health and the environment. That decision was based on the results of human health and ecological risk assessments, which determined that conditions at the site pose no unacceptable risks to human health or the environment for expected or future use of the SRPA beneath the deep-perched water system at the RTC. One of the assumptions for the no-remedial-action decision was that groundwater monitoring would be performed to verify that contaminant concentration trends follow those predicted by the OU 2-12 computer model. It was further stated in the OU 2-12 ROD (DOE-ID 1992) that a statutory review of this decision would be conducted by the Agencies (i.e., U.S. Department of Energy Idaho Operations Office, Idaho Department of Environmental Quality, and EPA) within 3 years to ensure that adequate protection of human health and the environment continues to be provided.

The results from the OU 2-12 groundwater monitoring are described in a series of three annual technical memoranda. Following 3 years of groundwater monitoring, the results from the entire OU 2-12 post-ROD monitoring were described in the Post-Record of Decision Monitoring for the Test 
Reactor Area Perched Water System Operable Unit 2-12, Third Annual Technical Memorandum (Arnett, Meachum, and Jessmore 1996), which presented 3 years of post-ROD monitoring data and included an evaluation of hydrologic and groundwater contaminant conditions for the RTC deep-perched water system and the underlying SRPA. The results from this Technical Memorandum were then incorporated into the Comprehensive Remedial Investigation/Feasibility Study for the Test Reactor Area Operable Unit 2-13 at the Idaho National Engineering and Environmental Laboratory (DOE-ID 1997b).

In December 1997, the OU 2-13 ROD was issued (DOE-ID 1997a). According to this ROD, the objectives of the groundwater monitoring program are to verify contaminant concentration trends in the SRPA, as predicted by computer modeling, and to evaluate the effect that discontinuing discharge to the warm waste pond has had on contaminant concentrations in the SRPA and the deep-perched water system. The First Five-Year Review Report for the Test Reactor Area, Operable Unit 2-13, at the Idaho National Engineering and Environmental Laboratory (DOE-ID 2003) recommended that only four COCs warranted continued semiannual groundwater monitoring, including chromium, tritium, strontium-90 (Sr-90), and cobalt-60 (Co-60). During 2002/2003, a deep corehole was drilled south-southwest of the RTC facility and completed as a monitoring well. This well, Middle-1823, was added to the list of monitoring wells for Waste Area Group (WAG) 2.

The investigation into the recurrence of diesel in perched water well PW-13 recommended that perched water wells with the strongest presence of diesel-PW-13, TRA-1933, and TRA-1934 — are to be monitored periodically to obtain sufficient organics data to identify contaminant trends, if possible.

In accordance with the requirements of the Federal Facility Agreement and Consent Order for the Idaho National Engineering Laboratory (DOE-ID 1991), quality-assured data collected during groundwater monitoring will be submitted to the Agencies no later than 120 days from the time of collection. Data summary submittals and updates of information will be transmitted on the status of trending data in the form of an annual report.

\subsection{Groundwater Monitoring Plan}

The purpose of this GMP is to guide the collection and analysis of groundwater samples to support the OU 2-13 post-ROD monitoring at the RTC. Development of this GMP was based on the

recommendations identified from the WAG 2 5-year reviews (DOE-ID 2003, 2006b) and the 2006 annual report (ICP 2006).

This GMP includes

- A description of the RTC site and a background discussion

- Development of sampling objectives and needs

- Determination of sample locations and frequency

- Specification of the sample designation to provide for unique identifiers for all samples collected

- $\quad$ Description of sampling procedures and equipment

- Documentation management and sample control requirements. 


\section{SITE DESCRIPTION AND BACKGROUND}

The INL Site is a government-owned reservation managed by the U.S. Department of Energy. The eastern boundary of the INL Site is located $52 \mathrm{~km}(32 \mathrm{mi})$ west of Idaho Falls, Idaho. The INL Site occupies approximately $2,305 \mathrm{~km}^{2}\left(890 \mathrm{mi}^{2}\right)$ of the northwestern portion of the Eastern Snake River Plain in southeast Idaho. The RTC is located in the west-central portion of the INL Site, as shown in Figure 2-1.

The RTC was established in the early 1950s for studying the effects of radiation on materials, fuels, and equipment. Three major reactors have been built at the RTC: (1) the Materials Test Reactor, (2) the Engineering Test Reactor, and (3) the Advanced Test Reactor. Currently, the Advanced Test Reactor is the only operating reactor at the RTC. A detailed description of RTC is available in the OU 2-13 ROD (DOE-ID 1997a).

\subsection{Source, Nature, and Extent of Contamination}

Infiltration of wastewater from the pond system at RTC has caused the migration of contaminants to the deep-perched water system and ultimately to the SRPA. In addition, the TRA disposal well disposed of wastewater from the cold waste sampling pit (TRA-764) into the SRPA until 1982 when the well was taken out of service and turned into a monitoring well. This disposal well was the primary source of chromium contamination in the aquifer since the water in the cooling towers was treated with chromate to inhibit corrosion. The total amount of chromium discharged to the disposal well from January 1, 1964, through December 31, 1972, is approximately 14,121 kg (31,131 lb). According to the Comprehensive RI/FS for the Idaho Chemical Processing Plant OU 3-13 at the INEEL_Part A, RI/BRA Report (Final) (DOE-ID 1997c), the amount of chromium and tritium discharged to the warm waste pond is estimated at $8,070 \mathrm{~kg}(17,791 \mathrm{lb})$ and $8,920 \mathrm{Ci}$, respectively.

According to the Post Record of Decision Monitoring Plan for the Test Reactor Area Perched Water System Operable Unit 2-12 (Dames and Moore 1993), the key contaminants in the groundwater included five radioactive constituents (Am-241, Cs-137, Co-60, Sr-90, and tritium) and eight chemical constituents (arsenic, beryllium, cadmium, chromium, cobalt, fluoride, lead, and manganese). Monitoring for these contaminants was performed from 1993 through 1996.

Following this period of monitoring, the approach to groundwater monitoring at RTC was modified to incorporate results from the previous 3 years of monitoring, recommending changes to the monitoring frequency and analyte list, as identified in the Third Annual Technical Memorandum (Arnett, Meachum, and Jessmore 1996). Since January 1997, RTC groundwater monitoring involved semiannual sampling for chromium, cadmium, tritium, Co-60, and Sr-90 from the wells identified in the OU 2-12 Groundwater Monitoring Plan (Dames and Moore 1993). These changes to the RTC groundwater monitoring were approved by the Agencies in November 1996 in accordance with written correspondence.

With the completion of the first WAG 2 Five-Year Review (DOE-ID 2003), water quality results demonstrated little impact (most levels near detection limits) for Am-241, arsenic, beryllium, cadmium, cesium-137, fluoride, lead, manganese, and mercury. The COCs with higher concentrations included chromium, tritium, and Sr-90, with Co-60 concentrations being of a concern for the deep perched water. Based upon the recommendations provided in the first 5-year review, only these four COCs continue to warrant continued groundwater monitoring. The recurrence of diesel contamination in Well PW-13 was noted as an issue during the first 5-year review. Sampling for diesel-range organics (DROs) and gasoline-range organics (GROs) was added for PW-13, TRA-1933, and TRA-1934. 


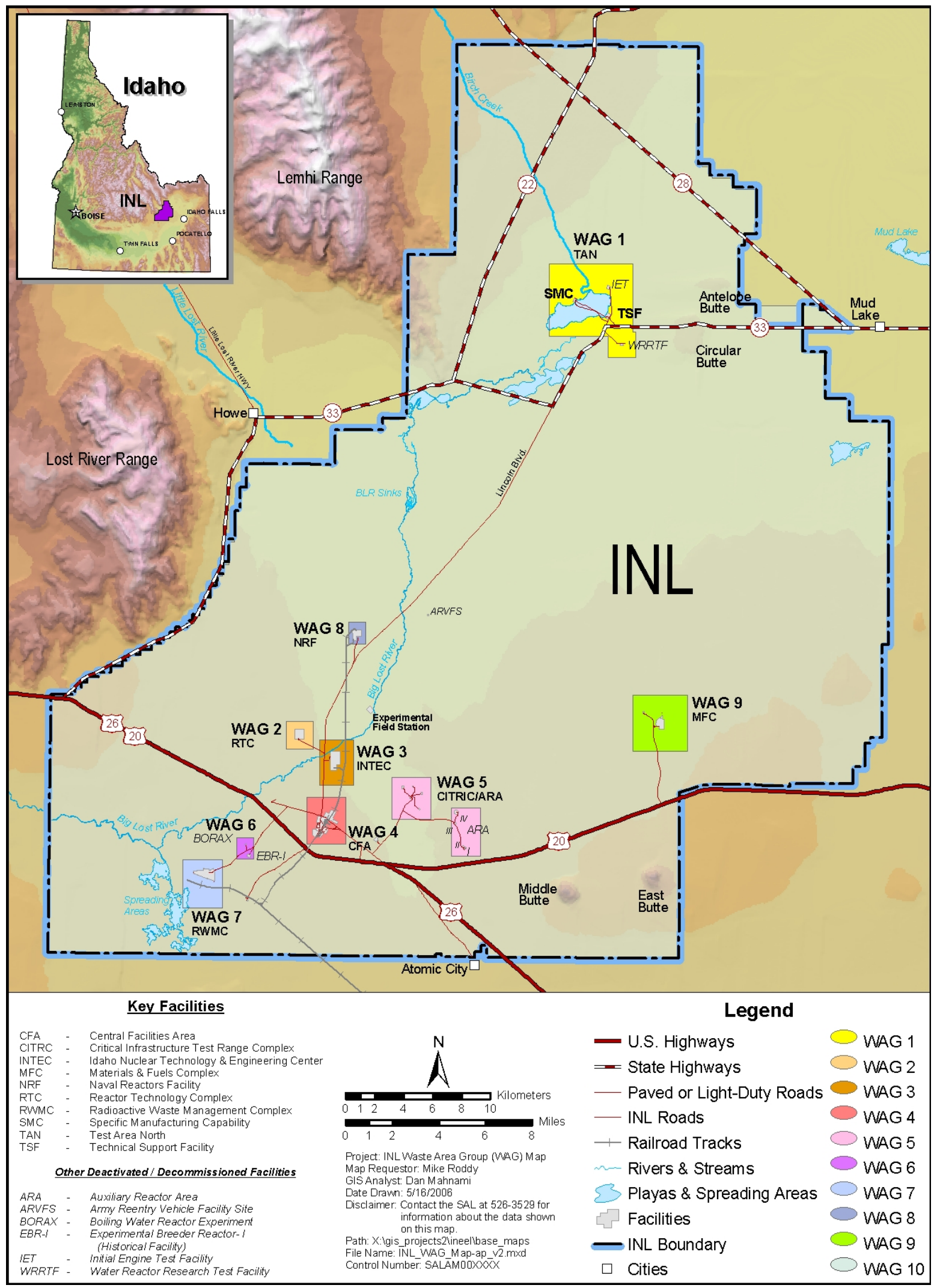

Figure 2-1. Map showing the location of the Idaho National Laboratory Site. 


\section{SAMPLING OBJECTIVES}

This section identifies the data needs required for conducting the proposed sampling in support of the WAG 2 groundwater monitoring activities. Data needs and data quality objectives (DQOs) are defined in the following subsections.

\subsection{Data Needs}

Data needs have been determined through the evaluation of existing data and the projection of data requirements anticipated for analysis of samples collected during WAG 2 groundwater monitoring. Groundwater monitoring was implemented as a component of the OU 2-12 and OU 2-13 RODs (DOE-ID 1992 and 1997a, respectively) to verify trends in the SRPA predicted by pre-ROD computer modeling and to ensure that the selected remedies remain protective of the groundwater. Based upon the data evaluation presented in the first WAG 2 Five-Year Review (DOE-ID 2003), it was recommended that monitoring of the perched and aquifer groundwater continue for a reduced list of analytes. The fiscal year (FY) 2006 annual monitoring report made the recommendation to reduce groundwater monitoring to an annual event from a twice a year monitoring program.

\subsubsection{Problem Statement}

The objective of DQO Step 1 is to use relevant information to clearly and concisely state the problem to be resolved. There are two basic parts to the problem. First, groundwater sampling results indicate that INL operations at RTC may have impacted the SRPA, causing contaminant concentrations in groundwater that exceed the EPA-defined regulatory levels. Second, it is important to assess the impact that continuing operations at RTC have on the groundwater.

Problem Statement 1-Contaminant Monitoring: Monitor the four COC concentration trends in the SRPA and the deep perched aquifer to verify the accuracy of the groundwater modeling predictions and ensure the protection of the water quality in the SRPA.

Problem Statement 2-Operations Impact: Assess the impact that continuing operations at RTC have on the groundwater through monitoring of the perched water systems underlying RTC.

\subsubsection{Decision Identification}

The goal of DQO Step 2 is to define the questions that the study will attempt to resolve and to identify the alternative actions that may be taken based on the outcome of the study. The defined questions and their corresponding alternative actions will then be joined to form decision statements (DSs). The principal study questions (PSQs) for WAG 2 groundwater monitoring are as follows:

- $\quad$ PSQ \#1-Do the concentrations of the four COCs in the SRPA underlying the RTC site exceed the EPA-defined regulatory levels and Idaho groundwater quality standards (IDAPA 58.01.11.200)?

- $\quad$ PSQ \#2-Do the trends of the contaminant concentrations in the perched water underlying the RTC site indicate that continuing operations are having an adverse impact on groundwater?

- $\quad$ PSQ \#3-Does the reoccurrence of diesel contamination in PW-13 represent residual product from the early 1980 s or an additional source of diesel? 
Alternative actions are those actions resulting from resolution of the stated PSQs. The types of alternative actions considered would depend on the answers to the PSQs. Given the PSQs developed for WAG 2 groundwater monitoring, the associated decision statements are as follows:

- DS \#1-Assess on an annual basis whether contaminant concentrations in the SRPA underlying the RTC site continue to exceed the EPA-defined regulatory levels and Idaho groundwater quality standards (IDAPA 58.01.11.200).

- $\quad$ DS \#2-Determine whether the trends of contaminant concentrations in the perched water underlying the RTC site indicate that continuing operations are having an adverse impact on the groundwater.

- $\quad$ DS \#3-Determine whether the trends of DRO and GRO contaminant concentrations in groundwater are consistent with residual diesel fuel from the early 1980s.

\subsubsection{Identify Inputs to the Decision}

The purpose of DQO Step 3 is to identify the type of data needed to resolve each of the decision statements identified in DQO Step 2. These data may already exist or may be derived from computational or surveying/sampling and analysis methods. Analytical performance requirements (e.g., practical quantitation limits, precision, and accuracy) also are provided in this step for any new data that will be collected.

3.1.3.1 Information Required to Resolve Decision Statements. Table 3-1 specifies the information (data) required to resolve each of the decision statements identified in Section 3.1.2 and identifies whether these data already exist. For the data that are identified as existing, the source references for the data have been provided with a qualitative assessment as to whether the data are of sufficient quality to resolve the corresponding decision statement. The qualitative assessment of the existing data was based on the evaluation of the corresponding quality control (QC) data (e.g., spikes, duplicates, and blanks), detection limits, and data collection methods.

Table 3-1. Required information and reference sources.

\begin{tabular}{|c|c|c|c|c|c|}
\hline DS \# & $\begin{array}{l}\text { Measurement } \\
\text { Variable }\end{array}$ & Required Data & $\begin{array}{c}\text { Do Data } \\
\text { Exist? }\end{array}$ & Source Reference & $\begin{array}{c}\text { Additional } \\
\text { Information } \\
\text { Required? }\end{array}$ \\
\hline 1 & $\begin{array}{l}\text { Radiochemical } \\
\text { and chemical } \\
\text { concentrations }\end{array}$ & $\begin{array}{l}\text { Laboratory measurement } \\
\text { of potential contaminants }\end{array}$ & Yes & 5 -year reviews ${ }^{\mathrm{a}}$ & Yes \\
\hline 2 & $\begin{array}{l}\text { Radiochemical } \\
\text { and chemical } \\
\text { concentrations }\end{array}$ & $\begin{array}{l}\text { Laboratory measurement } \\
\text { of potential contaminants }\end{array}$ & Yes & 5 -year reviews ${ }^{\mathrm{a}}$ & Yes \\
\hline 3 & DRO and GRO & $\begin{array}{l}\text { Laboratory measurement } \\
\text { of potential contaminants }\end{array}$ & Yes & $\begin{array}{l}5 \text {-year reviews, annual } \\
\text { reports } 2005 \text { and } 2006\end{array}$ & Yes \\
\hline \multicolumn{6}{|c|}{ a. 5-year reviews (DOE-ID 2003, 2006b). } \\
\hline
\end{tabular}


3.1.3.2 Basis for Setting the Action Level. The action level is the threshold value that provides the criterion for choosing between alternative actions. For Decision Statements 1 and 2, the COCs as identified in the first WAG 2 Five-Year Review (DOE-ID 2003) are chromium, Sr-90, Co-60, and tritium. The criteria for setting the action levels for the contaminants are the EPA-defined regulatory levels (e.g., drinking water standards) and the Idaho groundwater quality standards (IDAPA 58.01.11.200). For Decision Statement 3, an action level is not defined, but the action will depend on the success of the free product recovery and concentration trends for DRO and GRO in the perched water.

3.1.3.3 Computational and Survey/Analytical Methods. Table 3-2 identifies the decision statements where existing data either do not exist or are of insufficient quality to resolve the decision statements. For these decision statements, Table 3-2 presents computational and/or surveying/sampling methods that could be used to obtain the required data. For Decision Statements 1 and 2, analytical data will be collected to determine the concentrations of contaminants in the perched water and SRPA underlying WAG 2. For Decision Statement 2, the statistical trend of the contaminants will be determined to ascertain whether the potential exists for adversely affecting the SRPA in the future. For Decision Statement 3, analytical data will be collected to determine the trend of contaminants analyzed to evaluate potential impacts.

Table 3-2. Information required for resolution of decision statements.

\begin{tabular}{|c|c|c|c|c|}
\hline DS \# & $\begin{array}{l}\text { Measurement } \\
\text { Variable }\end{array}$ & Required Data & Computational Methods & Survey/Analytical Methods \\
\hline 1 & $\begin{array}{l}\text { Radiochemical } \\
\text { and chemical }\end{array}$ & $\begin{array}{l}\text { Radiochemical and } \\
\text { chemical } \\
\text { concentrations in the } \\
\text { SRPA }\end{array}$ & $\begin{array}{l}\text { Compare contaminant } \\
\text { concentrations to } \\
\text { regulatory levels }\end{array}$ & $\begin{array}{l}\text { Analytical laboratory } \\
\text { determination of contaminant } \\
\text { concentrations in groundwater }\end{array}$ \\
\hline 2 & $\begin{array}{l}\text { Radiochemical } \\
\text { and chemical }\end{array}$ & $\begin{array}{l}\text { Radiochemical and } \\
\text { chemical } \\
\text { concentrations in the } \\
\text { perched water }\end{array}$ & $\begin{array}{l}\text { Obtain statistical trend of } \\
\text { contaminant } \\
\text { concentrations over time }\end{array}$ & $\begin{array}{l}\text { Analytical laboratory } \\
\text { determination of contaminant } \\
\text { concentrations in groundwater }\end{array}$ \\
\hline 3 & DRO and GRO & $\begin{array}{l}\text { DRO and GRO } \\
\text { concentrations in } \\
\text { perched water and free } \\
\text { product }\end{array}$ & $\begin{array}{l}\text { Obtain statistical trend of } \\
\text { contaminant } \\
\text { concentrations over time }\end{array}$ & $\begin{array}{l}\text { Analytical laboratory } \\
\text { determination of contaminant } \\
\text { concentrations in groundwater }\end{array}$ \\
\hline \multicolumn{5}{|c|}{$\begin{array}{l}\text { DRO = diesel-range organics. } \\
\text { DS = decision statement. } \\
\text { GRO = gasoline-range organics. }\end{array}$} \\
\hline
\end{tabular}

3.1.3.4 Analytical Performance Requirements. Table 3-3 defines the analytical performance requirements for the data that need to be collected to resolve each of the decision statements. These performance requirements include the practical quantitation limit, precision, and accuracy requirements for each of the potential contaminants. 
Table 3-3. Analytical performance requirements.

\begin{tabular}{|c|c|c|c|c|c|c|}
\hline DS \# & Analyte List & $\begin{array}{l}\text { Survey/ } \\
\text { Analytical } \\
\text { Method } \\
\end{array}$ & $\begin{array}{c}\text { Preliminary } \\
\text { Action Level }\end{array}$ & $\begin{array}{c}\text { Practical } \\
\text { Quantitation } \\
\text { Limit } \\
\end{array}$ & $\begin{array}{c}\text { Precision } \\
\text { Requirement }\end{array}$ & $\begin{array}{c}\text { Accuracy } \\
\text { Requirement }\end{array}$ \\
\hline 1,2 & $\begin{array}{l}\text { Chromium } \\
\text { Sr-90 } \\
\text { Co-60 } \\
\text { Tritium }\end{array}$ & $\begin{array}{l}\text { SW-846 } \\
\text { GFPC } \\
\text { Gamma spec. } \\
\text { LSC }\end{array}$ & $\begin{array}{l}\text { EPA and } \\
\text { IDAPA } \\
\text { regulatory } \\
\text { levels }\end{array}$ & See QAPjP & $\pm 20 \%$ & $80-120 \%$ \\
\hline 3 & DRO and GRO & $\mathrm{SW}-846^{\mathrm{a}}$ & $\begin{array}{l}\text { Not } \\
\text { applicable }\end{array}$ & See QAPjP & $\begin{array}{c}\text { Not } \\
\text { applicable }\end{array}$ & $\begin{array}{l}\text { Not } \\
\text { applicable }\end{array}$ \\
\hline $\begin{array}{l}\text { a. EPA } \\
\text { DRO = } \\
\text { DS = de } \\
\text { EPA = } \\
\text { GFPC = } \\
\text { GRO = } \\
\text { IDAPA } \\
\text { LSC = 1 } \\
\text { QAPjP }\end{array}$ & $\begin{array}{l}\text { 1998). } \\
\text { liesel-range organics. } \\
\text { ision statement. } \\
\text {.S. Environmental P1 } \\
\text { gas-flow proportiona } \\
\text { asoline-range organi } \\
=\text { Idaho Administrati } \\
\text { quid scintillation cou } \\
\text { Quality Assurance } \mathrm{F}\end{array}$ & $\begin{array}{l}\text { ection Agency. } \\
\text { ounting. } \\
\text { Procedures Act. } \\
\text { ng. } \\
\text { ject Plan. }\end{array}$ & & & & \\
\hline
\end{tabular}

\subsubsection{Study Boundaries}

The primary objective of DQO Step 4 is to identify the population of interest, define the spatial and temporal boundaries that apply to each decision statement, define the scale of decision-making, and identify any practical constraints (hindrances or obstacles) that must be taken into consideration in the sampling design. Implementing this step ensures that the sampling design will result in the collection of data that accurately reflect the true condition of the site under investigation.

3.1.4.1 Geographic Boundaries. Limiting the geographic boundaries of the study area ensures that the investigation does not expand beyond the original scope of the task. This study will focus on the perched water and SRPA beneath RTC. Based on review of the hydraulic data and groundwater contour maps, the selected wells will allow for evaluation of the potential migration of groundwater contaminants.

3.1.4.2 Temporal Boundaries. The temporal boundary refers to the timeframe to which each decision statement applies (e.g., number of years) and when (e.g., season and time of day) the data should optimally be collected. Temporal boundaries are important when contaminant concentration changes over time are significant. Though historical data collected at RTC and other sites at the INL Site indicate that contaminant concentrations are unaffected by seasonal factors, the WAG 2 groundwater monitoring samples will be collected at approximately the same time of year (i.e., October timeframe). Samples will be collected annually and monitoring data reviewed with the Agencies. If sufficient data are collected to demonstrate that contaminant levels are constant or decreasing, the monitoring requirements/frequency may be reduced with concurrence by the Agencies. Changes to this GWP that are agreed to by the Agencies will be incorporated into a new revision of this GWP.

3.1.4.3 Scale of Decision-Making. The scale of decision-making is defined by joining the population of interest and the geographic and temporal boundaries of the area under investigation. For the WAG 2 groundwater monitoring, the scale of decision-making is the same as the geographic boundary defined in Section 3.1.4.1. 
3.1.4.4 Practical Constraints. Practical constraints may include physical barriers, difficult sample matrices, high radiation areas, or any other condition that will need to be considered in the design and scheduling of the sampling program. For WAG 2 groundwater monitoring, the primary constraint to be considered is whether water is present in the selected perched water wells. Historically, a number of the perched water wells listed have been dry. Given the reduced volumes of water being discharged into the cold waste pond at RTC, the occurrence of dry wells is anticipated to continue. If perched wells identified in this GWP for sampling go dry, then substitute wells will be used as identified in Section 4.2 of this GWP.

\subsubsection{Develop a Decision Rule}

The purpose of DQO Step 5 initially is to define the statistical parameter of interest (i.e., mean, 95\% upper confidence level) that will be used for comparison against the action level. The three decision rules (DRs) corresponding to the three decision statements provided in Section 3.1.2 are as follows:

- $\quad$ DR \#1-If the concentration of any of the four COCs exceeds the defined regulatory level for a given contaminant, the appropriate notifications will be made to the Agencies with continued monitoring.

- DR \#2- If the concentration of any of the four COCs indicates that concentrations are increasing, then monitoring will be continued and whether more aggressive action is necessary will be determined by concurrence with the Agencies. Conversely, if the trend indicates that contaminant concentrations are decreasing, then the monitoring frequency and target analytes may be reduced.

- $\quad$ DR \#3-If DRO and GRO concentrations in groundwater from PW-13, TRA-1933, and TRA-1934 indicate declining concentrations, then the need for additional monitoring will be reevaluated.

These DRs summarize the attributes the decision-maker needs to know about the sample population and how this knowledge will guide the selection of a course of action to solve the problem.

\subsubsection{Decision Error Limits}

Because analytical data can only estimate the true condition of the site under investigation, decisions that are made based on measurement data could potentially be in error (i.e., decision error). For this reason, the primary objective of DQO Step 6 is to determine which decision statements (if any) require a statistically based sample design. The purpose of determining the decision error limits is to specify the decision-maker's tolerable limits on decision errors, which are used to establish performance goals for the data collection design.

Tolerable error limits assist in the development of sampling designs to ensure that the spatial variability and sampling frequency are within specified limits. However, the sampling design for the WAG 2 groundwater monitoring is determined by well location and is based on professional judgment rather than statistics. Therefore, error limits are not used to determine sampling locations or frequency.

For the decision statement to be resolved using a nonstatistical design (e.g., Decision Statement 1), there is no need to define the "gray region" or the tolerable limits on the decision error since these only apply to statistical designs. While a statistical sampling design is not applicable to trend analysis as required for resolution of Decision Statement 2, a level of significance needs to be established over which it can be determined whether a significant trend does exist. For WAG 2 groundwater monitoring, a 95\% significance level will be used to determine whether a trend in the data exists. Given the level of significance, the following null hypothesis was developed: 
Null Hypothesis - A significant positive trend in the data exists.

\subsubsection{Optimize the Design}

The objective of DQO Step 7 is to present alternative data collection designs that meet the minimum data quality requirements, as specified in DQO Steps 1 through 6. A selection process is then used to identify the most resource-effective data collection design that satisfies all of the data quality requirements.

The following subsections present the selected technology and sampling methods for resolving each decision statement, along with a summary of the proposed implementation design. The basis for the selected implementation design is also provided.

3.1.7.1 Groundwater Monitoring. Monitoring will be performed from groundwater monitoring wells on an annual basis. Samples will be sent to off-Site laboratories for analysis with full quality assurance/quality control (QA/QC) protocols. The Sampling and Analysis Plan (SAP) tables will be generated prior to sampling. Water levels will be measured prior to sampling and used to determine groundwater elevations to complete groundwater elevation maps for the perched water and the aquifer.

3.1.7.2 Trend Analysis. Various statistical tests exist to determine whether a significant temporal trend exists in a given data set. For simple linear regression, the statistical test of whether the slope is significantly different from zero is equivalent to testing if the correlation coefficient is significantly different from zero. To perform the test, the correlation coefficient is first calculated (Equation 3-1). This correlation coefficient is then used to calculate the t-statistic (Equation 3-2), which is then compared to the critical value for $t_{1-\alpha / 2}$ to determine whether there is a significant correlation between the two variables (in this case, an analyte's concentration versus time). Historical and current data sets will be combined to perform the trend analysis. These equations are as follows:

$$
r=\frac{\sum_{i=1}^{n} X_{i} Y_{i}-\frac{\sum_{i=1}^{n} X_{i} \sum_{i=1}^{n} Y_{i}}{n}}{\left(\left(\sum_{i=1}^{n} X_{i}^{2}-\frac{\left(\sum_{i=1}^{n} X_{i}\right)^{2}}{n}\right)\left(\sum_{i=1}^{n} Y_{i}^{2}-\frac{\left(\sum_{i=1}^{n} Y_{i}\right)^{2}}{n}\right)\right)^{1 / 2}}
$$

where

$$
\begin{aligned}
& \mathrm{r}=\text { correlation coefficient for a given analyte } \\
& \mathrm{X}_{\mathrm{i}}=\text { the year of sample collection } \\
& \mathrm{Y}_{\mathrm{i}}=\quad \text { individual concentrations for a given analyte. }
\end{aligned}
$$




$$
t=\frac{r}{\sqrt{\frac{1-r^{2}}{n-2}}}
$$

where

$$
\begin{array}{ll}
\mathrm{t} & =\text { the calculated } \mathrm{t} \text {-test statistic } \\
\mathrm{r} & =\text { correlation coefficient for a given analyte calculated in Equation 3-1 } \\
\mathrm{n} & =
\end{array}
$$

If the calculated $t$ is greater than $t_{n-2,1-\alpha}$ as obtained from a table of statistical $t$-values, then the null hypothesis is rejected, and it can be concluded that there is no significant positive statistical trend in the data. Conversely, if the calculated $t$ is less than $t_{n-2,1-\alpha}$ as obtained from a table of statistical $t$-values, then the null hypothesis is not rejected, and it can be concluded that there is a significant positive statistical trend in the data.

\subsection{Quality Assurance Objectives for Measurement}

The QA objectives for measurement will meet or surpass the minimum requirements for data quality indicators established in the QAPjP (DOE-ID 2006a). This reference provides minimum requirements for the following measurement quality indicators: precision, accuracy, representativeness, detection limits, completeness, and comparability. Precision, accuracy, and completeness will be calculated per the QAPjP (DOE-ID 2006a).

\subsubsection{Precision}

Precision is a measure of the reproducibility of measurements under a given set of conditions. In the field, precision is affected by sample collection procedures and by the natural heterogeneity encountered in the environment. Overall precision (field and laboratory) can be evaluated by the use of duplicate samples collected in the field. Greater precision is typically required for analytes with very low action levels that are close to background concentrations.

Laboratory precision will be based upon the use of laboratory-generated duplicate samples or matrix spike/matrix spike duplicate samples. Evaluation of laboratory precision will be performed during the method data validation process. The frequency of the laboratory precision samples, such as matrix spike/matrix spike duplicate, will be at least one per groundwater sampling event or as needed for the method data validation process.

Field precision will be based upon the analysis of collected field duplicate or split samples. For samples collected for laboratory analyses, a field duplicate will be collected at a minimum frequency of 1 in 20 environmental samples.

\subsubsection{Accuracy}

Accuracy is a measure of bias in a measurement system. Laboratory accuracy is demonstrated using laboratory control samples, blind QC samples, and matrix spikes. Evaluation of laboratory accuracy will be performed during the method data validation process. Sample handling, field contamination, and the sample matrix in the field affect overall accuracy. By evaluating results from field blanks, trip blanks, 
and equipment rinsates, false positive or high-biased sample results will be assessed. Accuracy of field instrumentation will be ensured through the use of appropriate calibration procedures and standards.

\subsubsection{Representativeness}

Representativeness is a qualitative parameter that expresses the degree to which the sampling and analysis data accurately and precisely represent the characteristic of a population parameter being measured at a given sampling point or for a process or environmental condition. Representativeness will be evaluated by determining whether measurements are made and physical samples are collected in such a manner that the resulting data appropriately measure the media and phenomenon studied. The comparison of all field and laboratory analytical data sets obtained throughout this remedial action will be used to ensure representativeness.

\subsubsection{Detection Limits}

Detection limits will meet or exceed the risk-based or decision-based concentrations for the COCs. Detection limits will be as specified in the Sample and Analysis Management (formerly the Sample Management Office) Laboratory Master Task Agreement Statements of Work, Task Order Statements of Work, and as described in the QAPjP (DOE-ID 2006a).

\subsubsection{Completeness}

Completeness is a measure of the quantity of usable data collected during the field sampling activities. The QAPjP (DOE-ID 2006a) requires that an overall completeness goal of $90 \%$ be achieved for noncritical samples. If critical parameters or samples are identified, a $100 \%$ completeness goal is specified. Critical data points are those sample locations or parameters for which valid data must be obtained in order for the sampling event to be considered complete. Given that this is a monitoring project, all field screening and laboratory data will be considered noncritical with a completeness goal of $90 \%$.

\subsubsection{Comparability}

Comparability is a qualitative characteristic that refers to the confidence with which one data set can be compared to another. At a minimum, comparable data must be obtained using unbiased sampling designs. If sampling designs are not unbiased, the reasons for selecting another design should be well documented. Data comparability will be assessed through the comparison of all data sets collected during this study for the following parameters:

- Data sets will contain the same variables of interest.

- Units will be expressed in common metrics.

- Similar analytical procedures and QA will be used to collect data.

- $\quad$ Time of measurements of variables will be similar.

- Measuring devices will have similar detection limits.

- Samples within data sets will be selected in a similar manner.

- The number of observations will be of the same order of magnitude. 


\subsubsection{Data Validation}

Method data validation is the process whereby analytical data are reviewed against set criteria to ensure that the results conform to the requirements of the analytical method and any other specified requirements.

All laboratory-generated analytical data will be validated to Level "B" per Idaho Cleanup Project (ICP) Guide (GDE) -7003, "Levels of Analytical Method Data Validation." Field-generated data will not be validated. Quality of the field-generated data will be ensured through adherence to established operating procedures and use of equipment calibration, as appropriate. 


\section{SAMPLING LOCATION AND FREQUENCY}

The material presented in this section is intended to support the DQOs summarized in Section 3.

\subsection{Quality Assurance/Quality Control Samples}

The QA samples will be included to satisfy QA requirements for the field operations per the QAPjP (DOE-ID 2006a). The duplicate, blank, and calibration QA/QC samples will be analyzed as outlined in Section 3.

\subsection{Sampling Locations and Analytes}

The wells selected for the OU 2-13 post-ROD monitoring and the rationale for inclusion in the monitoring network are described below. Table 4-1 provides the necessary well construction information (e.g., date drilled, total depth, screen interval, casing diameter). Figure 4-1 shows the locations of aquifer wells relative to the RTC facility and Figure 4-2 shows the location of the perched wells.

Monitoring activities have been designed to verify the contaminant concentration trends in the SRPA, predicted by the OU 2-12 computer model, and to evaluate the effects that discontinued discharge to the warm waste pond has on the underlying water bodies. In addition, the deep-perched water system will be monitored for potential contaminant migration driven by continued discharges to the cold waste pond. To meet these objectives, groundwater monitoring will be performed on seven wells completed in the deep-perched water system (PW-9, PW-11, PW-12, PW-14, USGS-054, USGS-055, and USGS-056) and seven wells completed in the SRPA (Hwy-3, TRA-06A, TRA-07, TRA-08, USGS-058, USGS-065, and Middle-1823).

Water samples will be collected annually from the above wells for the four COCs that warrant continued groundwater monitoring, including chromium, tritium, Sr-90, and Co-60. Both filtered and unfiltered chromium samples will be collected. Wells will also be analyzed for gross alpha and gross beta in FY 2008 due to questionable detections of Sr-90 in recent sampling events. The need to continue performing gross alpha and gross beta analyses will be made on an annual basis. In addition, $\mathrm{PW}-13$, TRA-1933, and TRA-1934 will be sampled for DROs and GROs to address the occurrence of diesel at these locations.

During recent sampling events, two of the United States Geological Survey (USGS) perched wells (USGS-055 and USGS-056) have not had any water present. In the event that these wells are dry, the following wells shall be sampled in their place:

- $\quad$ For USGS-055, substitute USGS-070

- $\quad$ For USGS-056, substitute USGS-068.

Additionally, if PW-9 is dry, then either USGS-053 or USGS-073 will be substituted. 
Table 4-1. Well construction information.

\begin{tabular}{|c|c|c|c|c|c|c|}
\hline Well & $\begin{array}{c}\text { Date } \\
\text { Installed }\end{array}$ & $\begin{array}{c}\text { Total } \\
\text { Depth } \\
(\mathrm{ft})\end{array}$ & $\begin{array}{l}\text { Well Screen/ } \\
\text { Open Hole }\end{array}$ & $\begin{array}{c}\text { Screened } \\
\text { Interval(s) } \\
(\mathrm{ft} \mathrm{bls})\end{array}$ & Pump & $\begin{array}{l}\text { Casing } \\
\text { Diameter } \\
\text { (in.) } \\
\end{array}$ \\
\hline PW-11 & 1990 & 134.5 & $\begin{array}{l}\text { Stainless-steel } \\
\text { well screen }\end{array}$ & $109-129$ & Submersible & $4^{\mathrm{a}}$ \\
\hline PW-12 & 1990 & 133 & $\begin{array}{l}\text { Stainless-steel } \\
\text { well screen }\end{array}$ & $108-128$ & Submersible & $4^{\mathrm{a}}$ \\
\hline PW-13 & 1990 & 148.5 & $\begin{array}{l}\text { Stainless-steel } \\
\text { well screen }\end{array}$ & $57.5-87.5$ & None & 4 \\
\hline PW-14 & 1990 & 126 & $\begin{array}{l}\text { Stainless-steel } \\
\text { well screen }\end{array}$ & $93-123$ & Submersible & $4^{\mathrm{a}}$ \\
\hline TRA-1933 & 2004 & 103 & $\begin{array}{l}\text { Stainless-steel } \\
\text { well screen }\end{array}$ & $60-90$ & None & 4 \\
\hline TRA-1934 & 2004 & 100 & $\begin{array}{l}\text { Stainless-steel } \\
\text { well screen }\end{array}$ & $65-95$ & None & 4 \\
\hline PW-09 & 1986 & 200 & Perforated steel & $140-200$ & Submersible & 6 \\
\hline USGS-054 & 1960 & 91 & Open hole & $60-91$ & Submersible & 6 \\
\hline USGS-055 & 1960 & 81 & Open hole & $45-80$ & Submersible & 6 \\
\hline USGS-056 & 1960 & 80 & Open hole & $59-80$ & Submersible & 6 \\
\hline Hwy-3 & 1967 & 750 & Open hole & $680-750$ & Submersible & 8 \\
\hline TRA-06A & 1990 & 562 & $\begin{array}{l}\text { Stainless-steel } \\
\text { well screen }\end{array}$ & $528-558$ & Submersible & $4^{\mathrm{a}}$ \\
\hline TRA-07 & 1990 & 501 & $\begin{array}{l}\text { Stainless-steel } \\
\text { well screen }\end{array}$ & $463-493$ & Submersible & $4^{\mathrm{a}}$ \\
\hline TRA- 08 & 1990 & 501.5 & $\begin{array}{l}\text { Stainless-steel } \\
\text { well screen }\end{array}$ & $471.5-501.5$ & Submersible & $4^{\mathrm{a}}$ \\
\hline USGS-058 & 1961 & 503 & Open hole & $218-473$ & Submersible & 6 \\
\hline USGS-065 & 1960 & 498 & Open hole & $456-498$ & Submersible & 6 \\
\hline Middle-1823 & 2003 & 729.7 & $\begin{array}{l}\text { Stainless-steel } \\
\text { well screen }\end{array}$ & $680-720$ & Submersible & 6 \\
\hline \multicolumn{7}{|l|}{ Alternate Wells } \\
\hline USGS-053 & 1960 & 90 & $\begin{array}{l}\text { Perforated } \\
\text { casing }\end{array}$ & $\begin{array}{l}50-67 \\
75-80\end{array}$ & Submersible & 6 \\
\hline USGS-068 & 1960 & 128 & Open hole & $50-128$ & NA & 10 \\
\hline USGS-070 & 1961 & 100 & Open hole & $54.5-100$ & NA & 8 \\
\hline USGS-073 & 1961 & 127 & Open hole & $62-127$ & Submersible & 6 \\
\hline $\begin{array}{l}\text { a. Inside diameter. } \\
\text { bls }=\text { below land su } \\
\text { NA = not available }\end{array}$ & & & & & & \\
\hline
\end{tabular}




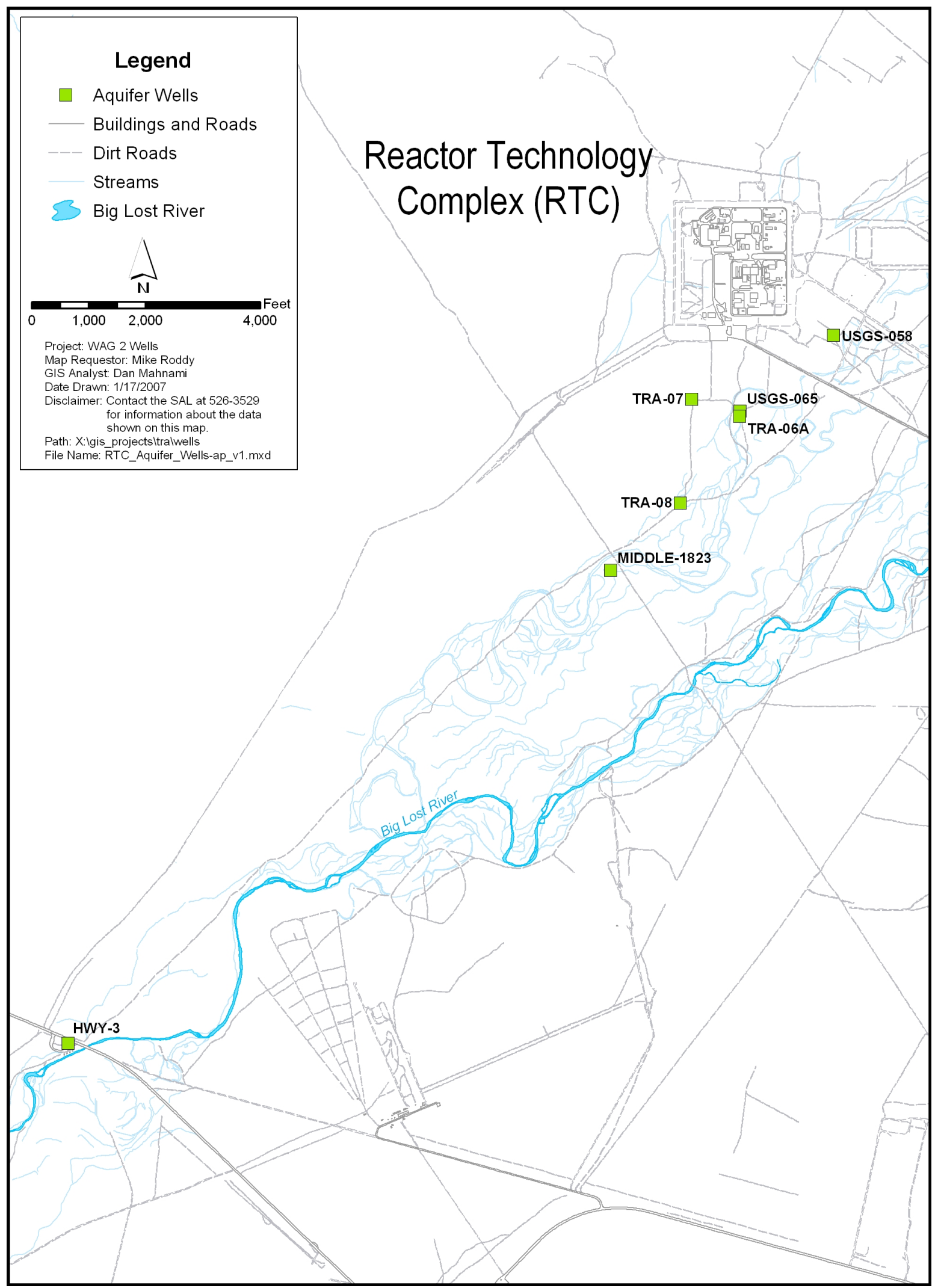

Figure 4-1. Map showing location of aquifer wells to be sampled at the Reactor Technology Complex. 


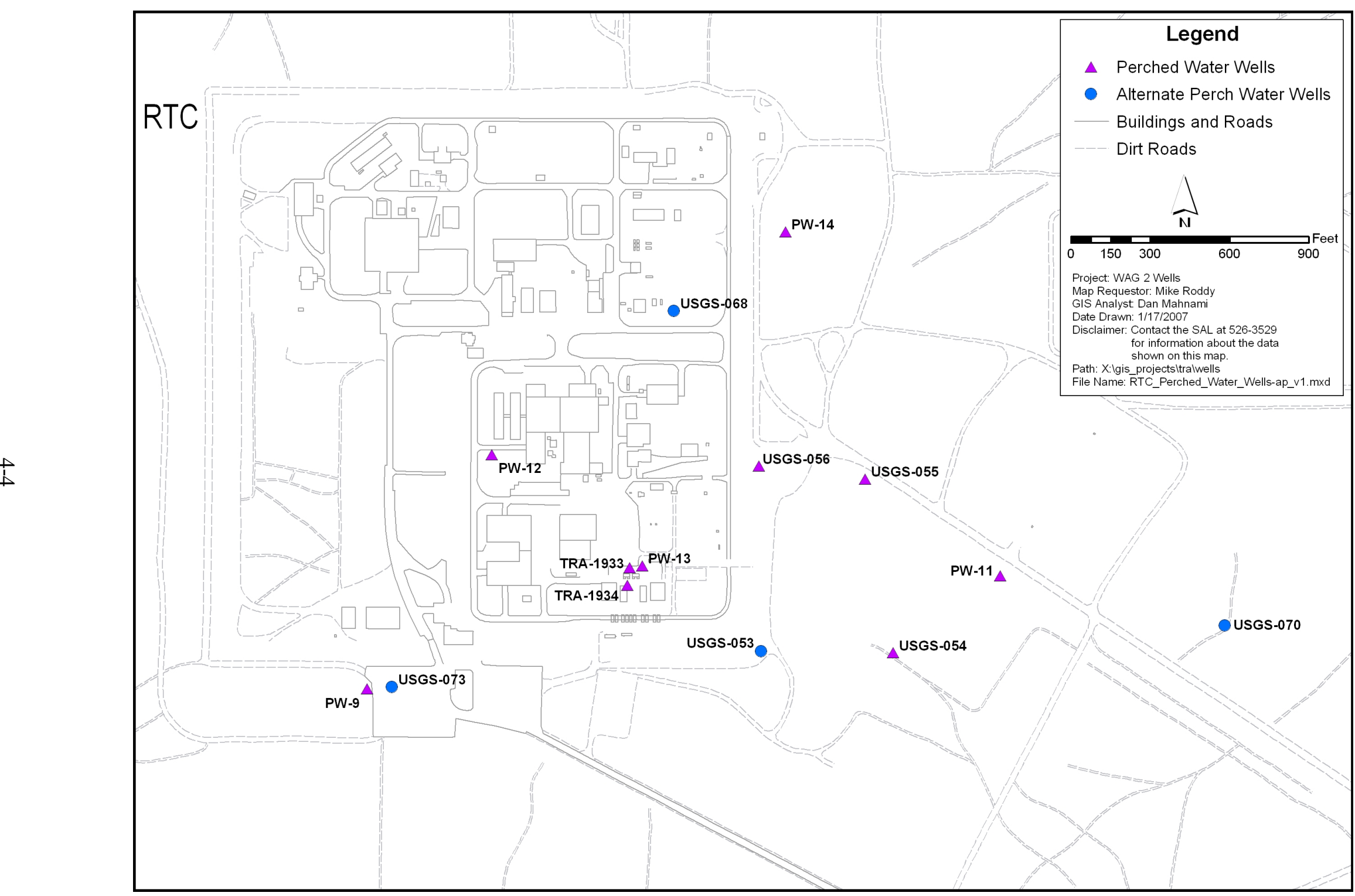

Figure 4-2. Map showing location of perched wells to be sampled at the Reactor Technology Complex. 


\subsection{Water Level Monitoring}

Water levels will be measured in perched and aquifer wells in a 2-day event prior to the annual sampling event in October. Water levels measured in this 2-day event will be used to calculate purge volumes for the subsequent sampling event. The perched and aquifer wells to be measured for water levels are shown on Figure 4-3. The perched and aquifer wells selected for water level measurements include several wells that will not be sampled but are needed to construct water level contour maps for the perched water and the aquifer in the vicinity of RTC. For FY 2007, water levels will be measured in March or May 2007 to generate water level contour maps for the aquifer and perched water. For FY 2008 and following years, water level measurements used to generate water level contour maps will be made during the annual sampling event each October.

\subsection{Petro Trap Monitoring}

The petro traps in PW-13, TRA-1933, and TRA-1934 will be checked monthly for the presence of free product with an interface probe. The petro traps will be pulled and checked for product with the volume of product recovered noted in the field logbook. If free product is present, the petro trap will be reinstalled and pulled again with the volume of product recovered noted. The petro trap will be inserted and pulled a maximum of 15 times when free-phase diesel is present (maximum removal of $10.5 \mathrm{~L}$ ). If after installing the trap an accumulation of less than $100 \mathrm{~mL}$ of diesel is collected in the trap after 30 minutes, then the removal of the trap is stopped until the next scheduled maintenance. The need to continue free product recovery using the petro trap will be evaluated on an annual basis. The free product recovery effort may be discontinued upon concurrence from the Agencies. 


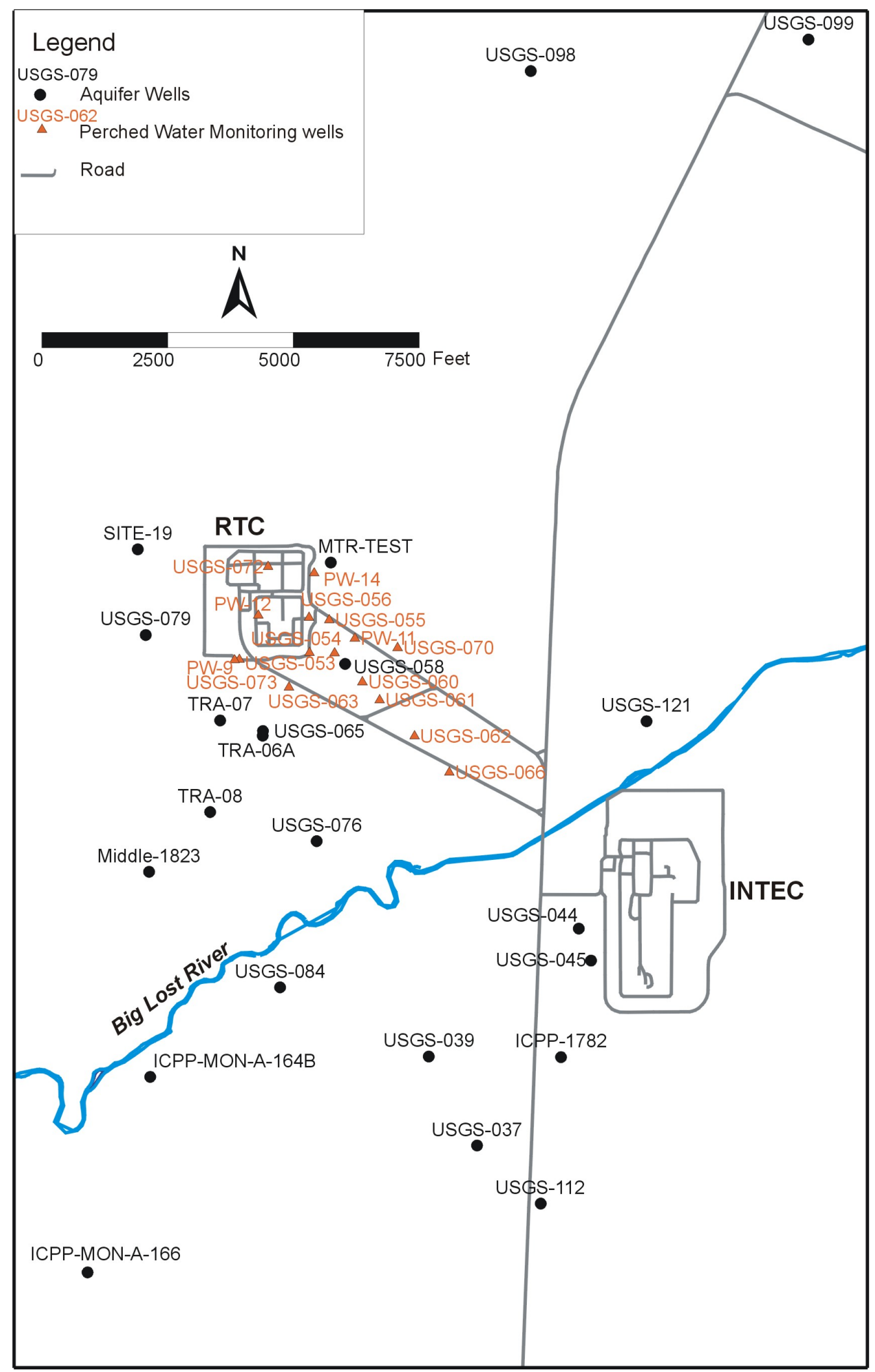

Figure 4-3. Water level measurement locations for perched and aquifer wells. 


\section{SAMPLING DESIGNATION}

\subsection{Sample Identification Code}

A systematic character identification (ID) code will be used to uniquely identify all samples. Uniqueness is required for maintaining consistency and preventing the same ID code from being assigned to more than one sample.

The first three designators of the code (TRA) refer to the sample originating from the Test Reactor Area, the former name for the Reactor Technology Complex. The next three numbers designate the sequential sample number for the project. The seventh and eighth characters represent a two-character set (e.g., 01, 02) for designation of field duplicate samples. The last two characters refer to a particular analysis and bottle type. Refer to the SAP tables prepared prior to each sampling event for specific bottle code designations.

For example, a groundwater sample collected in support of the post-ROD monitoring might be designated as TRA00101R4, where (from left to right):

- $\quad$ TRA designates the sample as being collected from the Test Reactor Area, now the RTC.

- 001 designates the sequential sample number.

- $\quad 01$ designates the type of sample $(01=$ original, 02 = field duplicate $)$.

- $\quad$ R4 designates gamma spectrometric analysis.

A SAP table/database will be used to record all pertinent information (e.g., well designation, media, date) associated with each sample ID code.

\subsection{Sampling and Analysis Plan Table/Database}

\subsubsection{Sampling and Analysis Plan Table}

A SAP table format was developed to simplify the presentation of the sampling scheme for project personnel. The following sections describe the information recorded in the SAP table/database. A SAP table will be generated prior to each sampling event.

\subsubsection{Sample Description}

The sample description fields contain information relating to individual sample characteristics.

5.2.2.1 Sampling Activity. The sampling activity field contains the first six characters of the assigned sample number. The sample number in its entirety will be used to link information from other sources (e.g., field data, analytical data) to the information in the SAP table for data reporting, sample tracking, and completeness reporting. The analytical laboratory will also use the sample number to track and report analytical results.

5.2.2.2 Sample Type. Data in this field will be selected from the following:

REG for a regular sample

QC for a QC sample. 
5.2.2.3 Media. Data in this field will be selected from the following:

GW for groundwater samples

WATER for QA/QC water samples.

5.2.2.4 Collection Type. Data in this field will be selected from the following:

$\begin{array}{ll}\text { GRAB } & \text { for grab sample collection } \\ \text { RNST } & \text { for rinsate QA/QC samples } \\ \text { DUP } & \text { for field duplicate samples } \\ \text { FBLK } & \text { for field blank QA/QC samples } \\ \text { TBLK } & \text { for trip blank QA/QC samples. }\end{array}$

5.2.2.5 Planned Date. This date is related to the planned sample collection start date.

\subsubsection{Sample Location Fields}

This group of fields pinpoints the exact location for the sample in three-dimensional space starting with the general AREA, narrowing the focus to an exact location geographically, and then specifying the DEPTH in the depth field.

5.2.3.1 Area. The AREA field identifies the general sample collection area. This field should contain the standard identifier for the INL Site area being sampled. For this investigation, samples are being collected from the Reactor Technology Complex, formerly the Test Reactor Area, and the AREA field identifier will correspond to that site.

5.2.3.2 Location. The LOCATION field may contain geographical coordinates, $x-y$ coordinates, building numbers, or other location-identifying details, as well as program-specific information such as borehole or well number. Data in this field will normally be subordinated to the AREA. This information is included on the labels generated by Sample and Analysis Management (formerly the Sample Management Office) to aid sampling personnel.

5.2.3.3 Type of Location. The TYPE OF LOCATION field supplies descriptive information concerning the exact sample location. Information in this field may overlap that in the location field, but it is intended to add detail to the location.

5.2.3.4 Depth. The DEPTH of a sample location is the distance in feet from surface level or a range in feet from the surface.

\subsubsection{Analysis Types}

5.2.4.1 AT1-AT20. These fields indicate analysis types (e.g., radiological, chemical, hydrological). Space is provided at the bottom of the form to clearly identify each type. A standard abbreviation also will be provided, if possible. 


\section{SAMPLING PROCEDURES AND EQUIPMENT}

This section describes the sampling procedures and equipment to be used for the planned groundwater monitoring. A pre-sampling meeting will be held before commencement of any sampling activities to review the requirements of this GMP and the latest revision of Miscellaneous Sites Cleanup Project Health and Safety Plan (PLN-2128) and to ensure that all supporting documentation has been completed.

\subsection{Groundwater Monitoring}

\subsubsection{Groundwater Elevations}

Groundwater elevations will be measured using either an electronic measuring tape (Solinst brand or equivalent) or a steel tape measure, as described in the latest ICP procedure for measuring groundwater levels. Measurement of all groundwater levels will be recorded to an accuracy of $0.01 \mathrm{ft}$. The use of automated data loggers for measuring groundwater levels may be implemented as funding becomes available. Water levels for perched and aquifer wells will be measured in a 2-day period prior to sampling. These measurements will be used to calculate purge volumes.

In addition to measuring water levels, free-product thickness will be measured in Wells PW-13, TRA-1933, and TRA-1934 using an interface probe. The interface probe will be used to measure the elevation of the diesel and the water in order to determine the thickness of the diesel in the well. The probe will be used as directed by the manufacturer.

\subsubsection{Well Purging}

Well purging will follow the latest ICP procedure. All wells, except Highway (Hwy) -3, that have sufficient water will be purged before sample collection. During the purging operation, a Hydrolab (or equivalent) will be used to measure specific conductance, $\mathrm{pH}$, and temperature. Samples for water quality analysis can be collected after a minimum of one well casing volume of water has been purged from the well and when three consecutive water quality parameter measurements are within the following limits:

- $\quad \mathrm{pH} \pm 0.2$

- $\quad$ Temperature $\pm 0.5^{\circ} \mathrm{C}$

- $\quad$ Specific conductance $\pm 5 \%$ of value.

If $\mathrm{pH}$, temperature, and specific conductance fail to stabilize within the above limits, purging will continue until three well casing volumes of water have been purged from the well, at which point sampling will commence regardless of stabilization. Some of the wells may have inadequate yields to supply sufficient purge volume. In that case, the well should be purged to dryness and sampled the next working day.

\subsubsection{Groundwater Sampling}

Before sampling, all nondedicated sampling equipment exposed to the water sample will be cleaned following the latest ICP procedure for decontaminating sample equipment. Following sampling, all nondedicated equipment that was exposed to the well water will be decontaminated in accordance with the latest ICP procedure before storage. An exception to following the latest procedure is that the isopropanol steps for decontamination will be omitted.

The water level for sampling and calculating purge volume in each well will be measured in the water level measurement event prior to sampling (see Section 4.3). Then the well will be purged a 
minimum of three well-casing volumes until the $\mathrm{pH}$, temperature, and specific conductance of the purge water have stabilized or until a maximum of five well-casing volumes have been removed. If the well goes dry before purging three well-casing volumes, purging will be considered complete and samples collected thereafter. If parameters are still not stable after five volumes have been removed, samples will be collected and appropriate notations will be recorded in the logbook.

Groundwater samples will be collected for the analyses defined in Section 3. The requirements for containers, preservation methods, sample volumes, and holding times will be specified in the laboratory Statement of Work to be prepared prior to sampling.

Sample bottles for groundwater samples will be filled to approximately $90-95 \%$ of capacity to allow for content expansion or preservation. Samples to be analyzed for chromium will be both unfiltered and filtered through a $0.45-\mu \mathrm{m}$ filter. Samples requiring acidification will be acidified to a $\mathrm{pH}<2$ using ultrapure nitric acid. The preferred order for sample collection is

- $\quad$ Temperature, $\mathrm{pH}$, specific conductance, and dissolved oxygen (during purging)

- $\quad$ GRO and DRO

- $\quad$ Chromium (filtered and unfiltered)

- $\quad$ Radionuclides (unfiltered).

\subsection{Handling and Disposition of Remediation-Derived Waste}

Remediation-derived Comprehensive Environmental Response, Compensation, and Liability Act (CERCLA) (42 USC § 9601 et seq.) waste will be generated at OU 2-13 as a result of the groundwater monitoring activities described herein. Waste anticipated to be generated as a result of the sampling activities conducted during this project includes the following:

- $\quad$ Personal protective equipment

- $\quad$ Purge water

- $\quad$ Liquid decontamination residue

- Solid decontamination residue

- $\quad$ Plastic sheeting

- $\quad$ Unused/unaltered sample material

- $\quad$ Sample containers

- $\quad$ Miscellaneous wastes

- $\quad$ Contaminated equipment.

Purge water from all wells, except Hwy-3, TRA-06A, and USGS-058, will be disposed of as directed by Waste Generator Services. Purge water from TRA-06A and USGS-058 will be discharged to the ground near the wellheads. Purging of the Hwy-3 well is not required, as the pump runs continuously. Water purged from Wells PW-13, TRA-1933, and TRA-1934 will require separate containment if diesel is present. Diesel-contaminated water will be disposed of as directed by Waste Generator Services. 
Waste generated during sampling activities will be managed in a manner that complies with the established applicable or relevant and appropriate requirements, protects human health and the environment, and achieves minimization of remediation waste to the extent possible. The CERCLA waste will be managed in accordance with the following management procedures, as applicable:

- MCP-1390, "Waste Generator Services Waste Management"

- MCP-3475, "Temporary Storage of CERCLA-Generated Waste at the INL Site"

- MCP-1396, "Waste Generator Services Management of CERCLA Waste for Disposal at ICDF." 
6-4 


\section{DOCUMENTATION MANAGEMENT AND SAMPLE CONTROL}

Section 7.1 summarizes document management and sample control. Documentation includes field logbooks used to record field data and sampling procedures, chain-of-custody forms, and sample container labels. Section 7.2 outlines the sample handling and discusses chain-of-custody, radioactivity screening, and sample packaging for shipment to the analytical laboratories. The analytical results from these sampling efforts will be documented in a series of technical memoranda that are prepared on an annual basis.

\subsection{Documentation}

The field team leader will be responsible for controlling and maintaining all field documents and records, and for ensuring that all required documents will be submitted to Document and Record Management. All entries will be made in permanent ink. All errors will be corrected by drawing a single line through the error and entering the correct information; all corrections will be initialed and dated.

\subsubsection{Sample Container Labels}

Waterproof, gummed labels generated from the SAP database will display information such as the sample ID number, the name of the project, sample location, and analysis type. In the field, labels will be completed and placed on the containers before collecting the sample. Information concerning sample date, time, preservative used, field measurements of hazards, and the sampler's initials will be filled out during field sampling.

\subsubsection{Field Guidance Forms}

Field guidance forms, which are provided for each sample location, will be generated from the SAP database to ensure unique sample numbers.

These forms are used to facilitate sample container documentation and organization of field activities, and they contain information regarding the following:

- $\quad$ Media

- $\quad$ Sample ID numbers

- $\quad$ Sample location

- $\quad$ Aliquot ID

- $\quad$ Analysis type

- Container size and type

- $\quad$ Sample preservation.

\subsubsection{Field Logbooks}

In accordance with Administrative Record and Document Control format, field logbooks will be used to record information necessary to interpret the analytical data. All field logbooks will be controlled and managed according to the latest ICP procedure for logbook practices. 
7.1.3.1 Sample/Shipping Logbook. The field teams will use sample logbooks. Each sample logbook will contain information such as

- $\quad$ Physical measurements (if applicable)

- $\quad$ All QC samples

- $\quad$ Shipping information (e.g., collection dates, shipping dates, cooler ID number, destination, chain-of-custody number, name of shipper)

- $\quad$ All team activities

- $\quad$ Problems encountered

- Visitor $\log$

- List of site contacts.

This logbook will be signed and dated at the end of each day's sampling activities.

7.1.3.2 Field Instrument Calibration/Standardization Logbook. A logbook containing records of calibration data will be maintained for each piece of equipment requiring periodic calibration or standardization. This logbook will contain log sheets to record the date, time, method of calibration, and instrument ID number.

\subsection{Sample Handling and Shipping}

All samples will be handled in accordance with the latest ICP procedure. Qualified (Sampling and Analysis Management-approved) analytical and testing laboratories will be used to analyze the groundwater samples.

\subsubsection{Sample Containers}

Analytical samples for laboratory analyses will be collected in pre-cleaned bottles and packaged in accordance with the QAPjP (DOE-ID 2006a).

\subsubsection{Sample Preservation}

Preservation of water samples will be performed before sample collection. The temperature will be checked periodically before shipment to certify adequate preservation for those samples requiring temperatures at $4^{\circ} \mathrm{C}\left(39^{\circ} \mathrm{F}\right)$ for preservation. Ice chests (coolers) containing frozen reusable ice will be used to chill samples, if required, in the field after sample collection.

\subsubsection{Chain-of-Custody Procedures}

The chain-of-custody procedures will follow the requirements of the latest ICP procedure for chain-of-custody and sample labeling. Sample bottles will be stored in a secured area, which is accessible only to the field team members.

\subsubsection{Transportation of Samples}

Samples will be shipped in accordance with the regulations issued by the U.S. Department of Transportation (DOT) (49 CFR 171 through 178) and EPA sample handling, packaging, and shipping methods (40 CFR 261.4[d]). All samples will be packaged in accordance with the latest ICP requirements. 
7.2.4.1 Custody Seals. Custody seals will be placed on all shipping containers in such a way as to ensure that sample integrity is not compromised by tampering or unauthorized opening. Clear-plastic tape will be placed over the seals to ensure that the seals are not damaged during shipment.

7.2.4.2 On-Site and Off-Site Shipping. An on-Site shipment is any transfer of material within the perimeter of the INL Site. Site-specific requirements for transporting samples within Site boundaries and those required by the Shipping/Receiving Department will be followed. Shipment within the INL Site boundaries will conform to DOT requirements, as stated in 49 CFR, "Transportation." Off-Site sample shipment will be coordinated with Packaging and Transportation Department personnel, as necessary, and will conform to all applicable DOT requirements.

\subsection{Document Revision Requests}

Revisions to this document will follow the latest ICP procedure for creating, modifying, and canceling controlled documents. 


\section{REFERENCES}

40 CFR 261.4(d), 2007, "Samples," Code of Federal Regulations, Office of the Federal Register, February 2007.

40 CFR 300, 2007, "National Oil and Hazardous Substances Pollution Contingency Plan," Code of Federal Regulations, Office of the Federal Register, March 2007.

49 CFR, 2007, “Transportation," Code of Federal Regulations, Office of the Federal Register, March 2007.

49 CFR 171, 2007, “General Information, Regulations, and Definitions," Code of Federal Regulations, Office of the Federal Register, February 2007.

49 CFR 172, 2007, "Hazardous Materials Table, Special Provisions, Hazardous Materials Communications, Emergency Response Information, and Training Requirements," Code of Federal Regulations, Office of the Federal Register, February 2007.

49 CFR 173, 2007, "Shippers-General Requirements for Shipments and Packagings," Code of Federal Regulations, Office of the Federal Register, February 2007.

49 CFR 174, 2006, "Carriage by Rail," Code of Federal Regulations, Office of the Federal Register, January 2006.

49 CFR 175, 2007, "Carriage by Aircraft," Code of Federal Regulations, Office of the Federal Register, February 2007.

49 CFR 176, 2007, "Carriage by Vessel," Code of Federal Regulations, Office of the Federal Register, January 2007.

49 CFR 177, 2006, "Carriage by Public Highway," Code of Federal Regulations, Office of the Federal Register, October 2006.

49 CFR 178, 2007, "Specifications for Packagings," Code of Federal Regulations, Office of the Federal Register, February 2007.

42 USC § 9601 et seq., 1980, "Comprehensive Environmental Response, Compensation and Liability Act of 1980 (CERCLA/Superfund)," United States Code, December 11, 1980.

Arnett, R. C., T. R. Meachum, and P. J. Jessmore, 1996, Post-Record of Decision Monitoring for the Test Reactor Area Perched Water System Operable Unit 2-12, Third Annual Technical Memorandum, INEL-96/0305, Idaho National Engineering and Environmental Laboratory, August 1996.

Dames and Moore, 1993, Post Record of Decision Monitoring Plan for the Test Reactor Area Perched Water System Operable Unit 2-12, EGG-ER-10547, Rev. 1, Idaho National Engineering and Environmental Laboratory, August 1993.

DOE-ID, 1991, Federal Facility Agreement and Consent Order for the Idaho National Engineering Laboratory, Administrative Record No. 1088-06-29-120, U.S. Department of Energy Idaho Operations Office; U.S. Environmental Protection Agency, Region 10; Idaho Department of Health and Welfare, December 4, 1991. 
DOE-ID, 1992, Record of Decision for the Test Reactor Area Perched Water System, Operable Unit 2-12, Doc. ID 5230, Rev. 0, U.S. Department of Energy Idaho Operations Office, December 1992.

DOE-ID, 1997a, Final Record of Decision for Test Reactor Area, Operable Unit 2-13, DOE/ID-10586, Rev. 0, U.S. Department of Energy Idaho Operations Office, December 1997.

DOE-ID, 1997b, Comprehensive Remedial Investigation/Feasibility Study for the Test Reactor Area Operable Unit 2-13 at the Idaho National Engineering and Environmental Laboratory, DOE/ID-10531, Rev. 0, U.S. Department of Energy Idaho Operations Office, February 1997.

DOE-ID, 1997c, Comprehensive RI/FS for the Idaho Chemical Processing Plant OU 3-13 at the INEEL-Part A, RI/BRA Report (Final), DOE/ID-10534, U.S. Department of Energy Idaho Operations Office, November 1997.

DOE-ID, 2003, First Five-Year Review Report for the Test Reactor Area, Operable Unit 2-13, at the Idaho National Engineering and Environmental Laboratory, DOE/ID-11099, Rev. 0, U.S. Department of Energy Idaho Operations Office, September 2003.

DOE-ID, 2005, Response to the First Five-Year Review Report for the Test Reactor Area, Operable Unit 2-13, at the Idaho National Engineering and Environmental Laboratory, DOE/NE-ID-11189, U.S. Department of Energy Idaho Operations Office, May 2005.

DOE-ID, 2006a, Quality Assurance Project Plan for Waste Area Groups 1, 2, 3, 4, 5, 6, 7, 10, and Removal Actions, DOE/ID-10587, Rev. 9, U.S. Department of Energy Idaho Operations Office, July 2006.

DOE-ID, 2006b, Five-Year Review of CERCLA Response Actions at the Idaho National Laboratory, DOE/NE-ID-11201, Rev. 1, U.S. Department of Energy Idaho Operations Office, June 2006.

EPA, 1998, Test Methods for Evaluating Solid Waste, Physical/Chemical Methods, current revision, SW-846, U.S. Environmental Protection Agency, April 1998.

GDE-7003, 2006, "Levels of Analytical Method Data Validation," Rev. 4, Sample and Analysis Administrative Manual, Idaho Cleanup Project, October 2006.

ICP, 2006, Annual Groundwater Monitoring Status Report for Waste Area Group 2 for Fiscal Year 2006, RPT-237, Rev. 1, Idaho Cleanup Project, October 2006.

IDAPA 58.01.11.200, 1997, “Ground Water Quality Standards,” Idaho Administrative Procedures Act, Department of Environmental Quality, March 1997.

MCP-1390, 2007, "Waste Generator Services Waste Management," Rev. 2, Idaho Cleanup Project, February 2007.

MCP-1396, 2007, "Waste Generator Services Management of CERCLA Waste for Disposal at ICDF," Rev. 6, Idaho Cleanup Project, February 2007.

MCP-3475, 2006, “Temporary Storage of CERCLA-Generated Waste at the INL Site," Rev. 5, Idaho Cleanup Project, November 2006.

PLN-2128, 2006, "Miscellaneous Sites Cleanup Project Health and Safety Plan," Rev. 2, Idaho Cleanup Project, October 2006. 